\title{
Causes of cracks of chemical apparatus made of austenitic steel
}

\begin{abstract}
Keywords:

austenitic steel;

stress cracks;

steam

The subject of the research was the installation of a water steam used in the chemical industry. Penetration tests revealed an extensive network of cracks on the surface of steel and welds. Metallographic studies, chemical composition analysis, EDX analysis were performed. Thermal treatment of steel was carried out and microhardness measurements were made. The results of the tests showed that stress corrosion was the main reason for the occurrence of cracks.
\end{abstract}

\section{Subject of the research}

The subject of the research was a fragment of the steam supply installation for chemical equipment. The tested element of the installation was made of austenitic stainless steel of $0 \mathrm{H} 18 \mathrm{~N} 9$ grade. This type of steel is often used in industry due to its excellent corrosion resistance, good plasticity and weldability $[1,2]$. Corrosion resistance is conditioned by its structure and homogeneity of the passive layer [3], in addition the corrosion resistance of this type of steel depends on the type of corrosive environment. Austenitic steels are susceptible for pitting corrosion and stress corrosion, especially in the environment containing chlorides [4]. An additional factor conducive to corrosion is the separation of chromium carbides reducing the content of chromium in the adjacent material, causing dechromination of grain boundaries [6]. They can be formed in the welding process. After a short period of operation of the tested installation, leakages were observed in the steam supply system. Penetration studies revealed an extensive network of cracks on the surface of the material, as shown in Figure 1.

The cracks occurred in the native material, in the welds and in the SWC zone. This generated the problem of determining the reason for the occurrence of cracks in the period of about one year.

\section{Research methodology}

In order to determine the causes of cracks, tests of the chemical composition of the native steel material and the weld material were performed, metallographic examinations were carried out on samples from various cracks (native material, SWC and weld) [5]. The sediment on the inner surface of the pipe was also tested. X-ray diffractometry and EDX analysis were performed using scanning electron microscope (SEM).

\section{Visual assessment}

On the injector's surface (Fig.1), visible cracks in all directions are visible to the unaided eye and cover the whole perimeter of the tube. Most visible cracks pass through the material. After cutting out the middle part of the pipe sample, in which the longitudinal weld connects to the peripheral one, its self-acting disintegration into smaller fragments shown in Figure 2 occured. A layer of brittle sediment was visible on the inner surface of the pipe.



Fig. 1. The appearance of the pipe after penetration tests

dr inż. Artur Lange, dr inż. Piotr Białucki, dr inż. Alyona Bashir, mgr inż. Ewa Harapińska - Wroclaw University of Science and Technology, Poland;

dr inż. Aleksandra Małachowska - Chemnitz University of Technology, Germany;

Corresponding author. artur.lange@pwr.edu.pl 


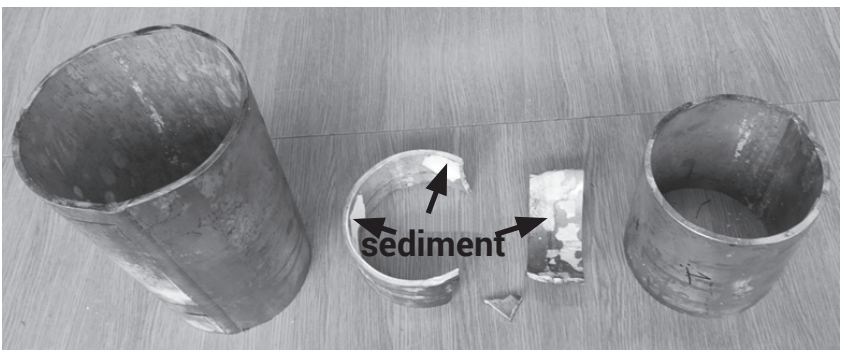

Fig. 2. View of the pipe fragments after cutting it open

Table I. Chemical composition of pipe and weld steel \%wg

\begin{tabular}{|c|c|c|c|c|}
\hline & $\begin{array}{c}\text { Steel 0H18N9 } \\
\text { by } \\
\text { PN-71/H-86020 }\end{array}$ & $\begin{array}{c}\text { Sample 1 } \\
\text { of steel of } \\
\text { pipe }\end{array}$ & $\begin{array}{c}\text { Sample 2 } \\
\text { of steel of } \\
\text { pipe }\end{array}$ & Weld \\
\hline C & 0,07 & 0,03 & 0,03 & 0,02 \\
\hline Si & 1,00 & 0,24 & 0,23 & 0,74 \\
\hline Mn & 2,00 & 1,86 & 1,87 & 0,91 \\
\hline P & 0,045 & 0,019 & 0,017 & 0,026 \\
\hline S & 0,015 & 0,081 & 0,084 & 0,126 \\
\hline $\mathrm{Mo}$ & - & 0,26 & 0,26 & 0,16 \\
\hline $\mathrm{Cr}$ & $17,5 \div 19,5$ & 17,61 & 17,68 & 18,59 \\
\hline $\mathrm{Ni}$ & $8,0 \div 10,5$ & 7,79 & 7,75 & 9,10 \\
\hline $\mathrm{Cu}$ & - & 0,32 & 0,32 & 0,13 \\
\hline $\mathrm{Co}$ & - & 0,24 & 0,25 & 0,11 \\
\hline
\end{tabular}

\section{Analysis of the chemical composition of the pipe material}

The analysis of the chemical composition of the steel was carried out using a spectral method using a LECO GDS750-QDP glow discharge spectrometer. After analysis of the chemical composition it was found that the injector's material corresponds to the $\mathrm{OH} 18 \mathrm{~N} 9$ grade steel (Tabl. I), in accordance with the requirements of the previous $\mathrm{PN}-\mathrm{H}-86020$ : 1971 [11]. According to the new PN-EN 10028-7:2016-09 [12], the steel equivalent to $0 \mathrm{H} 18 \mathrm{~N} 9$ is steel 1.4301 (304). The analysis showed only small deviations for nickel, whose content in steel is approx. $7.8 \%$ compared to $8.0 \%$ specified in the standard and sulfur. Increased sulfur content causes formation of manganese sulphides constituting local cathode areas, thus initiating pitting on the steel surface [7].

The chemical composition of the weld is suitable for the welded steel grade. The binder used contains a greater amount of chromium and nickel in relation to the native material and a reduced carbon content to protect against intercrystalline corrosion.

\section{Analysis of the sediment in the pipe}

The sediment located on the inner surface of the pipe, resulting from the contact with the medium - the calcareous leachate, was taken for analysis. The analysis was performed on a Hitachi S-3400N scanning microscope with an EDX adapter. Two sides of the collected sediment were analyzed from the medium side and from the injector' surface (Fig. 3 and 4). The results of measurements are presented in tables II and III. Particular attention is paid to the high
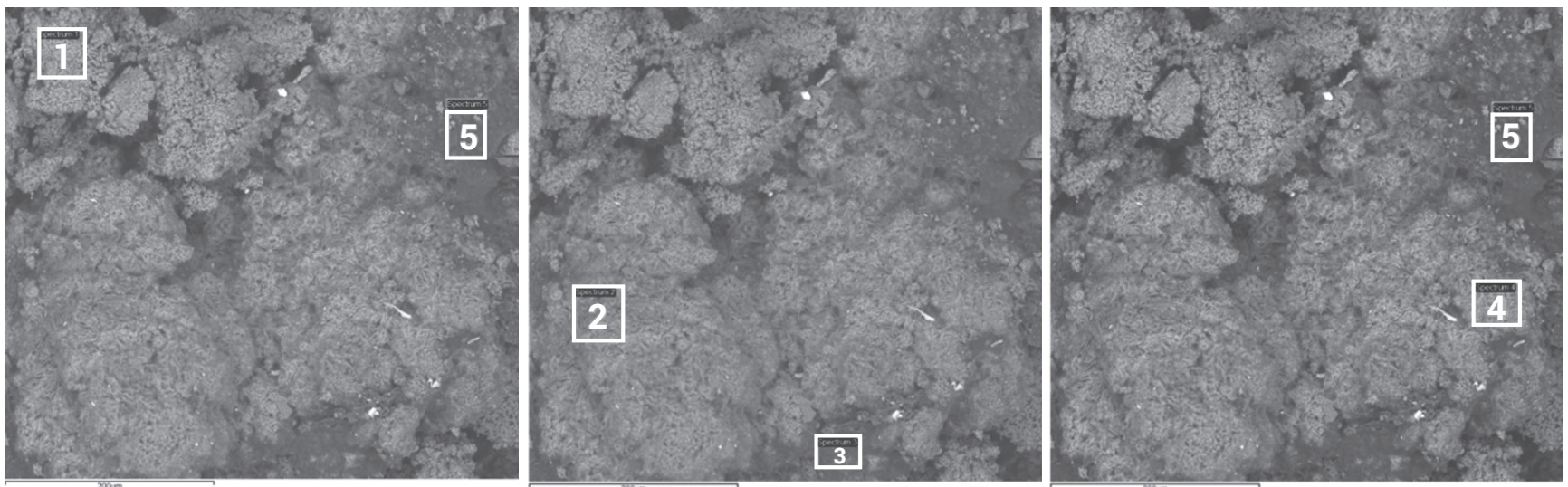

Fig. 3. Marked places where chemical composition was analyzed by means of EDX on the side of the sediment in contact with the medium - calcareous leachate, SEM

Table II. Composition of sediment from the medium side - calcareous leachate in \%wg

\begin{tabular}{|c|c|c|c|c|c|c|c|c|c|}
\hline Name & C & 0 & Mg & Al & $\mathrm{Si}$ & S & Cl & $\mathrm{Ca}$ & $\mathrm{Fe}$ \\
\hline Spectrum 1 & 12,223 & 30,066 & - & 1,126 & - & 0,450 & 2,907 & 53,228 & - \\
\hline Spectrum 2 & 19,729 & 55,685 & - & 0,198 & - & - & 0,484 & 23,570 & 0,334 \\
\hline Spectrum 3 & 12,740 & 27,888 & - & 1,455 & - & - & 1,670 & 56,247 & - \\
\hline Spectrum 4 & 14,751 & 47,879 & - & 0,317 & 0,235 & - & 1,146 & 35,672 & - \\
\hline Spectrum 5 & 18,984 & 39,838 & - & 0,364 & 0,174 & 0,287 & 2,828 & 37,525 & - \\
\hline
\end{tabular}


Table III. Composition of sediment on the surface side of the steel in \%wg

\begin{tabular}{|c|c|c|c|c|c|c|c|c|c|c|}
\hline Nazwa & $\mathbf{C}$ & $\mathbf{0}$ & $\mathbf{N a}$ & $\mathbf{M g}$ & $\mathbf{A l}$ & $\mathbf{S i}$ & $\mathbf{S}$ & $\mathbf{C l}$ & $\mathbf{C a}$ & $\mathbf{F e}$ \\
\hline Spectrum 1 & 15,452 & 41,342 & - & 0,299 & 1,033 & 2,614 & 1,887 & 10,314 & 19,311 & 7,746 \\
\hline Spectrum 2 & 17,344 & 43,320 & - & 1,709 & 0,919 & 1,338 & 0,557 & 9,943 & 23,369 & 1,501 \\
\hline Spectrum 3 & 14,570 & 44,621 & - & 1,006 & 1,059 & 2,556 & 1,292 & 8,987 & 17,407 & 8,501 \\
\hline Spectrum 4 & 16,058 & 41,385 & - & 0,430 & 0,591 & 0,950 & 0,472 & 7,959 & 30,930 & 1,225 \\
\hline
\end{tabular}
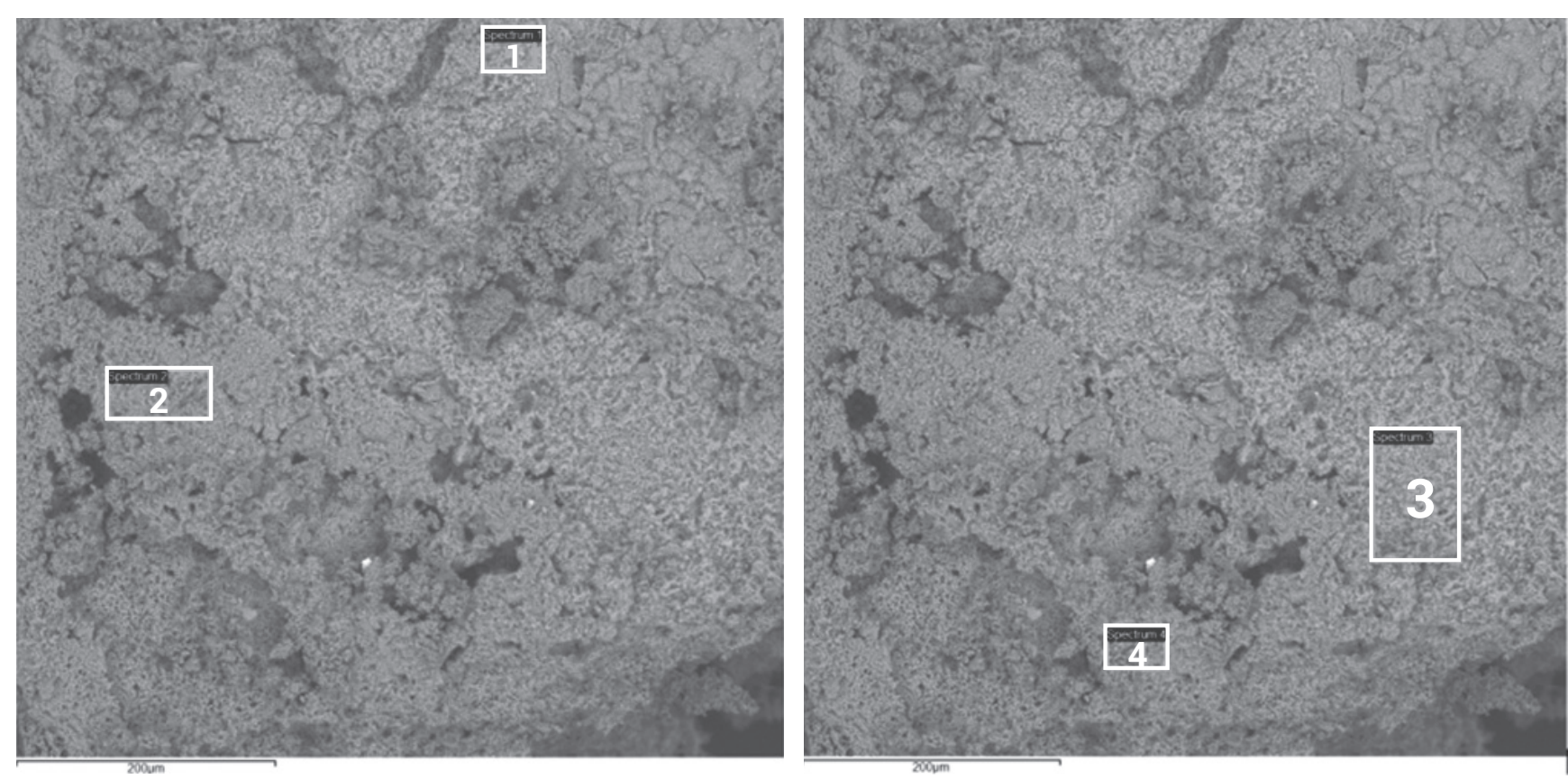

Fig. 4. Marked places where the chemical composition was analyzed by means of EDX on the surface of the sediment in contact with the inner wall of the pipe, SEM

chlorine content, which depending on the place of measurement reaches up to $10 \%$ by weight, which is a factor strongly conducive to such types of corrosion as: pitting, crevice and stress of the steel [8].

\section{Metallographic examinations}

Observations of the pipe material structures in the nonetched and etched state were carried out using the Neophot 32 Zeiss optical microscope and the Hitachi S-3400N scanning microscope.
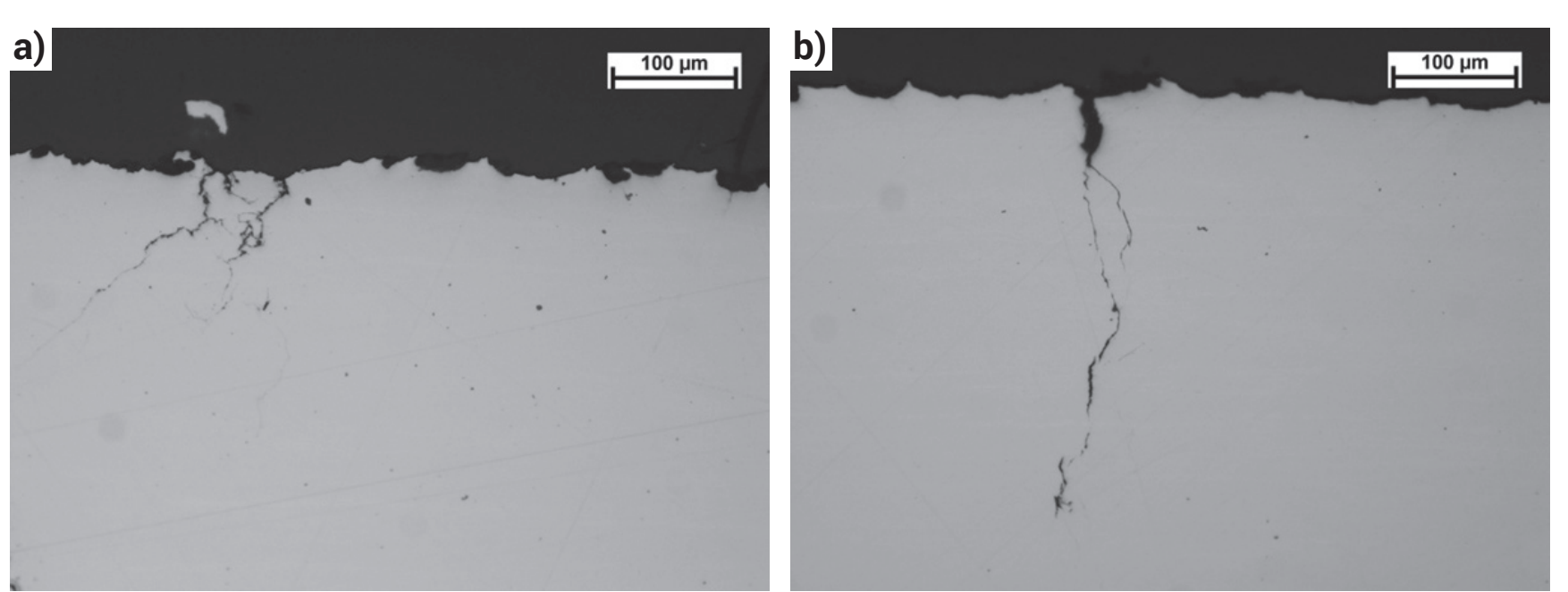

Fig. 5. $0 \mathrm{H} 18 \mathrm{~N} 9$ steel: a), b) corrosive cracks. Chrome carbides at grain boundaries. Light microscopy. Non-digested samples. Magn. 200x
Pictures of microstructures of the pipe material from various locations on the cross-sections of the taken samples are shown in Figures $5 \div 7$

Cracks visible in the pictures are typical for stress corrosion. Corrosive cracks run deep into the material, generally trans-crystalline, and branch out at the ends (Fig. 6). Such cracks occur in both steel and in the weld zone as well as in the heat affected zone (Fig. 7).

The chromium carbides visible at the grain boundary (Fig. 6) do not form a continuous net, but are arranged in separated precipitates. Only locally, on the part of the grain border, continuity of carbide precipitates can be noticed. This is 
a)

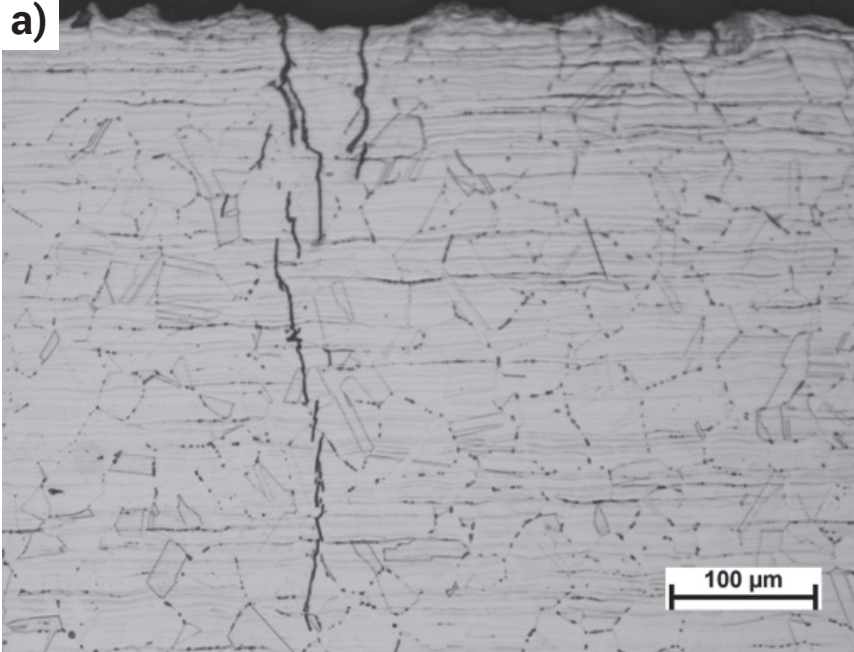

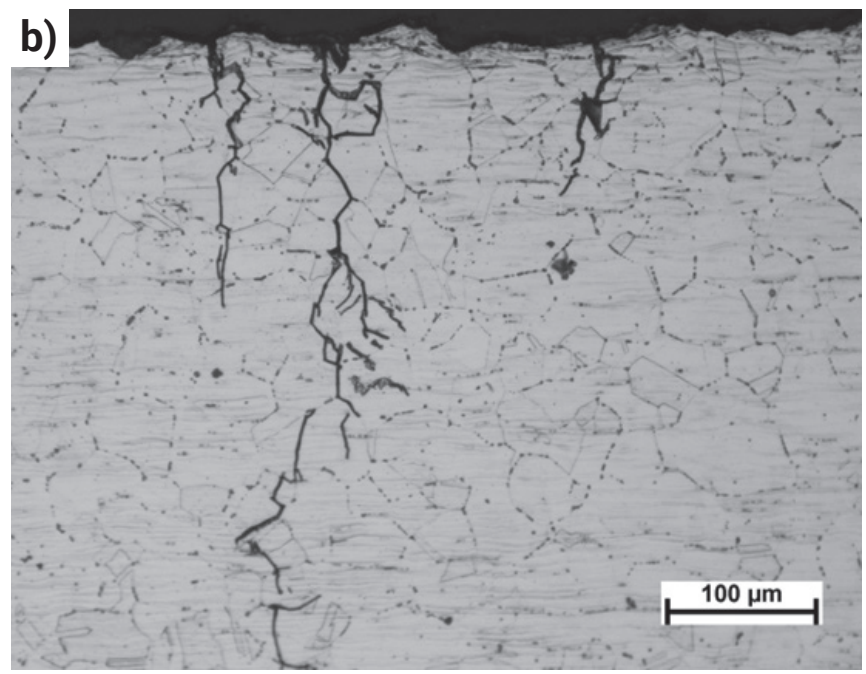

Fig. 6. $0 \mathrm{H} 18 \mathrm{~N} 9$ steel: a), b) corrosive cracks. Chrome carbides at grain boundaries. Light microscopy. Samples digested with Mi31Fe. Magn. 200x
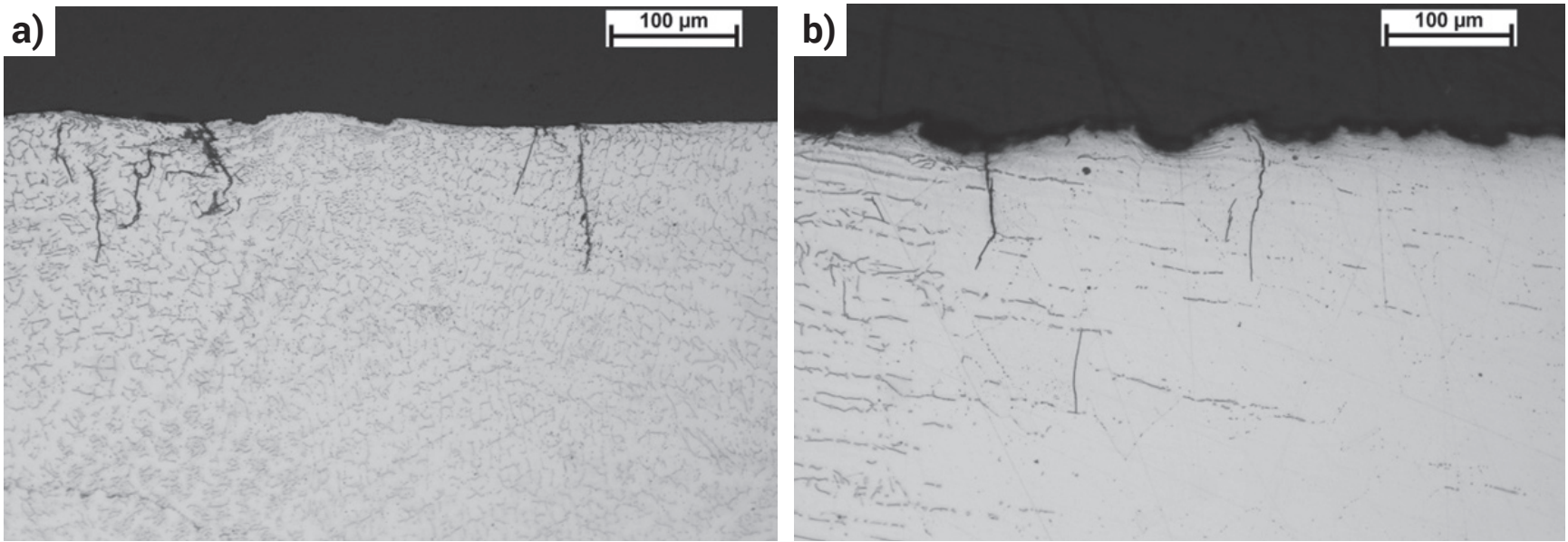

Fig. 7. Welded joint: a) weld structure, b) structure of the SWC zone. Light microscopy. Samples digested with Mi31Fe. Magn. 200x

confirmed by the results of investigations of microstructures made with a SEM microscope (Fig. 8 $\div 9$ ) of samples with cracks. The chemical composition analysis was made from the fragment of material marked in Figure 8. The presence of separated carbides confirms the results of the analysis of the chemical composition of the precipitates, shown in Figure 9 and Table IV.

It can therefore be concluded that in the case of the pipe under test, intercrystalline corrosion was not the reason for the material cracking. It should be noted, however, that

a)

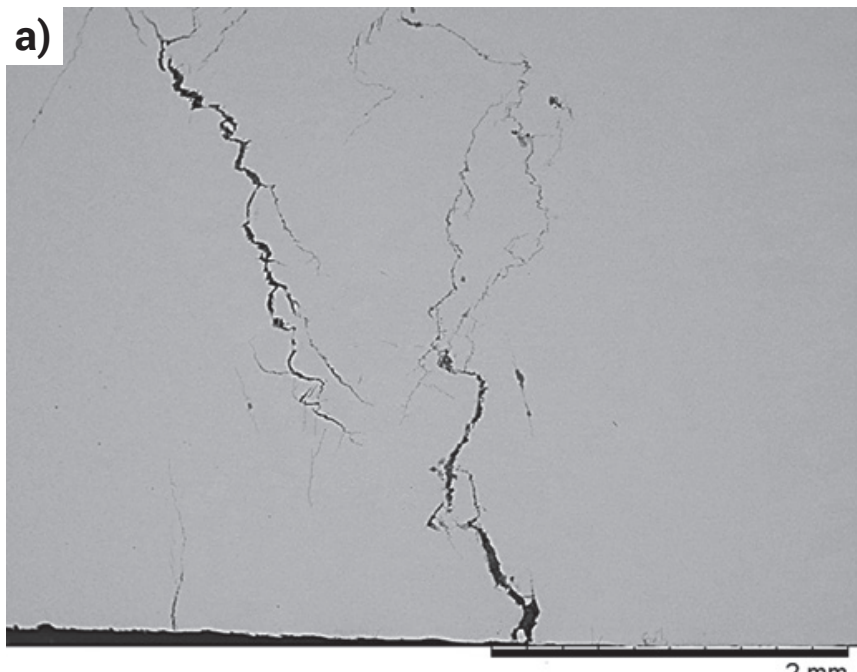

the occurrence of carbide precipitates and presence of tensile stresses promotes the occurrence of stress corrosion.

\section{Heat treatment of a pipe section}

In order to reduce the susceptibility to intercrystalline corrosion, heat treatment was carried out. Two samples were collected from the same injector fragment, one of which was heat treated (supersaturated at $1090{ }^{\circ} \mathrm{C}$ in air, followed

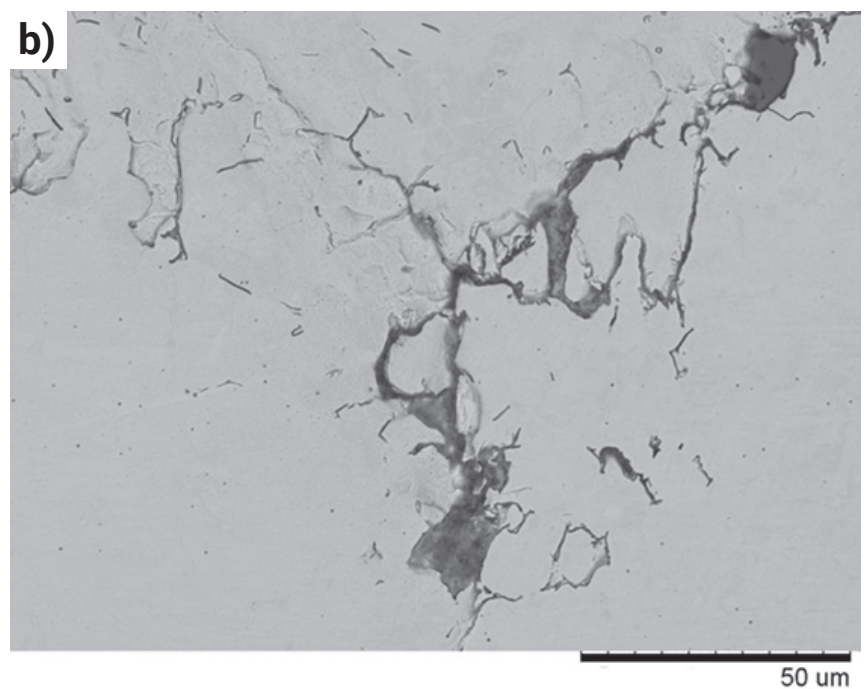

Fig. 8. Cross-section of a pipe section: a) corrosion cracking, b) enlarged crack fragment, SEM 
Table IV. Composition of precipitates visible in the cross-section of injector's section in \%wg

\begin{tabular}{|c|c|c|c|c|c|c|c|c|}
\hline Nazwa & C & $\mathbf{0}$ & Si & S & Cr & Mn & Fe & Ni \\
\hline Spectrum 1 & 19,100 & 3,121 & 0,851 & - & 19,858 & 1,358 & 52,164 & 3,547 \\
\hline Spectrum 2 & 27,575 & 4,289 & 0,693 & - & 17,201 & 1,230 & 44,850 & 4,163 \\
\hline
\end{tabular}

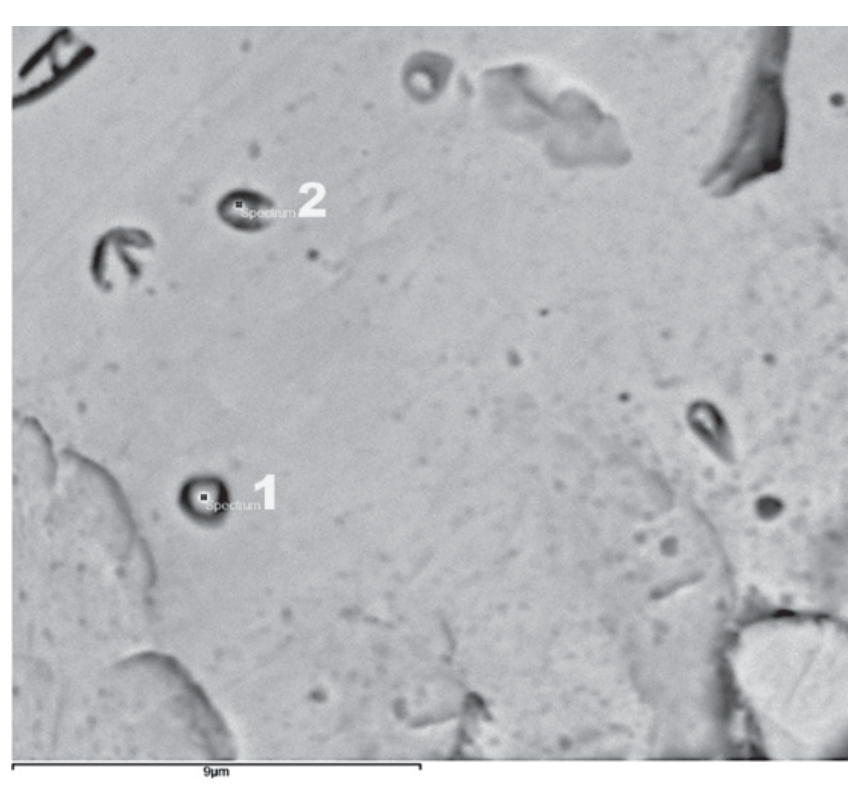

Fig. 9. Marked places where the chemical composition of precipitates was analyzed by means of EDX
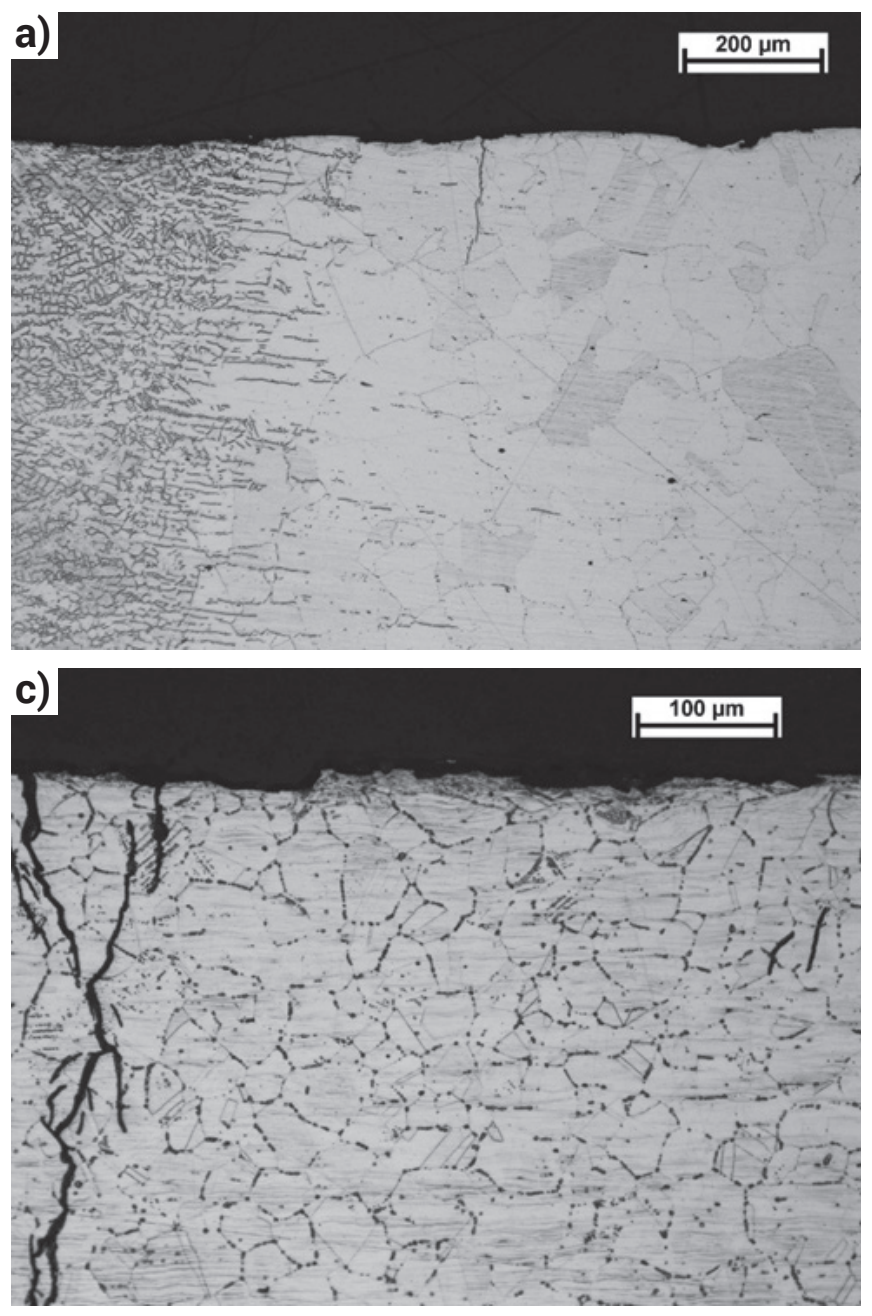

by rapid cooling in water) [14]. The structure of the samples was then compared (Fig. 7).

\section{Metallographic analysis}

Heat treatment caused a decrease in the amount of carbides in the steel structure as a result of their dissolution in the material's matrix and an increase in grain size (Fig. 10 and 11). The hardness was also significantly reduced in both the parent material and the weld (Fig. 12 and 13). Before the heat treatment, the hardness was about $180 \mathrm{HV} 0.1$ and after heat treatment about 150 HV0.1 PN-EN 1043-1:2000. Heat treatment removes residual stresses, which increase the likelihood of stress corrosion [9], as well as the removal of some of the precipitates that may be the origin of pitting.

\section{Hardness measurement}

The hardness measurement was carried out using the Vickers method on a Sinowon HVS1000 hardness tester at a load of $0.98 \mathrm{~N}$ which corresponds to HV0.1 PN-EN 1043-1: 2000. As a result of hardness measurements, it was found that the hardness of the weld is similar to the hardness of the native material.

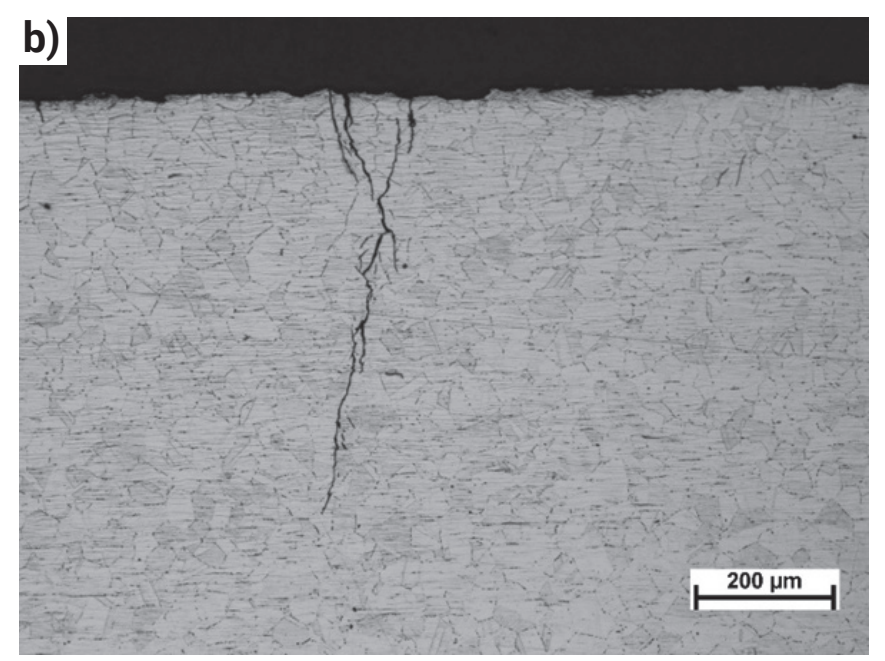

Fig. 10. Cross-sections of pipe sections before heat treatment: a) SWC area, Magn. $x 100, b)$ native material, Magn. $x 100, c)$ native material, Magn. x200. Samples digested with Mi31Fe 



Fig. 11. Cross-sections of sections from the tube material after heat treatment: a) corrosion crack visible on the austenite background, b) austenite. Samples digested with Mi31Fe. Magn. x200

a)



b)

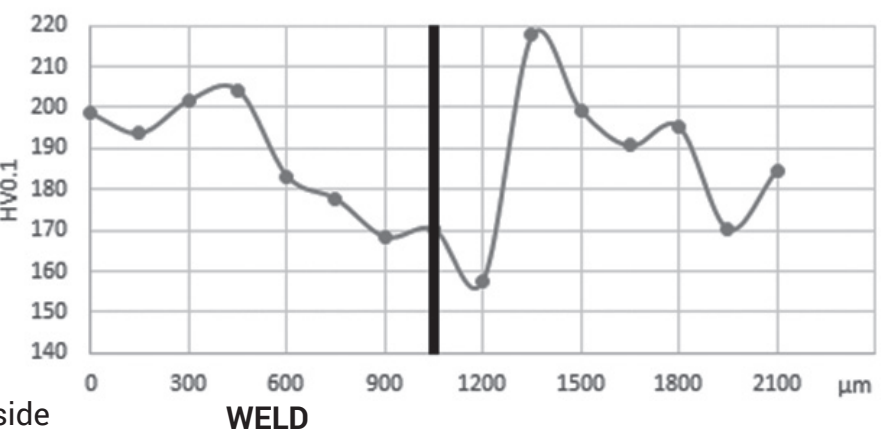

Measurement perpendicular to the axis of the weld

Fig. 12. Hardness graphs for a weld before heat treatment: a) measurement perpendicular to the axis of the weld, b) measurement perpendicular to the sheet metal surface, c) measurement scheme

a)

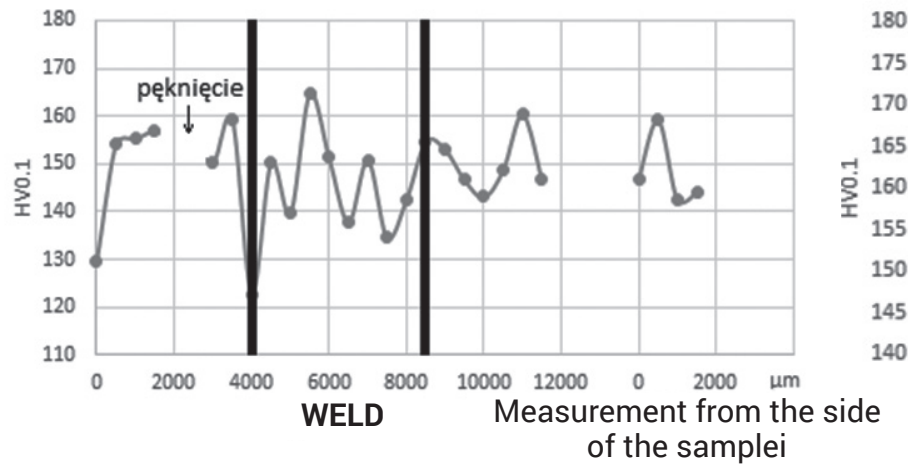

b)

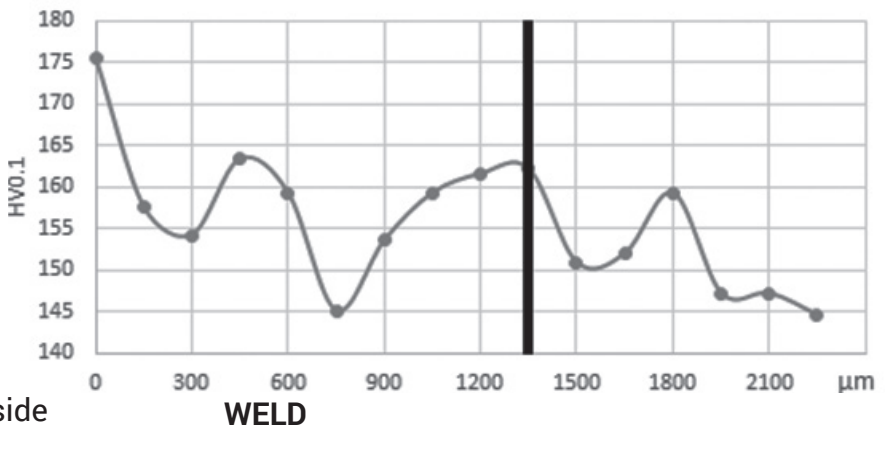

Fig. 13. Hardness graphs for a weld after heat treatment: a) measurement perpendicular to the axis of the weld, b) measurement perpendicular to the axis of the sheet metal

\section{Summary}

The steel used to make the $\mathrm{OH} 18 \mathrm{~N} 9$ grade pipe belongs to austenitic stainless steels, characterized by very good weldability and ease of plastic forming. It owes its good anti-corrosion properties to the phenomenon of passivation, consisting in the formation of a film of oxides on the surface of the metal that hinders further corrosion processes. However, in the presence of chlorides, the passive film penetrates and initiates pitting corrosion. This phenomenon takes place especially in the areas of weakening of the passive film - the pores, the heterogeneity of the structure, e.g. non-metallic inclusions. If the element additionally includes tensile stresses, the material does not repassivate and local crack propagates the crack leading to the destruction of the element. This is a typical course of stress corrosion, to which the $0 \mathrm{H} 18 \mathrm{~N} 9$ steels are not resistant. 
The nucleation and development of steel corrosion cracking arises due to factors such as:

- high surface roughness,

- heterogeneity of the microstructure (separation at the grain boundary, inclusions, etc.),

- operational environment (high concentration of chlorides),

- own and delayed stresses,

- increased temperature (sometimes even $50^{\circ} \mathrm{C}$ ).

In case of the pipe being analyzed, most of these conditions occurred.

Probably after the welding process the injector was not subjected to a stress-relieving treatment, so there were tensile stresses in the medium with which the element had a high concentration of chlorides, the pipe worked at a temperature of approx. $250^{\circ} \mathrm{C}$. This caused the occurrence of stress corrosion and destruction of the element. Also chromium carbides in the operating environment are formed by corrosion microcells, in which the carbide is a cathode and the adjacent metal is an anode, causing intercrystalline corrosion [13]. Under the influence of stresses, microcracks form on the boundaries of austenite grains weakened by intercrystalline corrosion, which caused the development of corrosion cracking.

An additional factor influencing the development of corrosion could be the insulation covering the pipe, which blocked the access of oxygen, which made it difficult to restore the damaged passive layer.

Considering that steel $0 \mathrm{H} 18 \mathrm{~N} 9$ can withstand the concentration of chlorine ions up to $1000 \mathrm{ppm}$ [9] in the case of the medium flowing, the durability of installations made of this steel can be increased by subjecting the whole element or construction to supersaturation treatment. Performing only a stress relief treatment after welding may not be sufficient to eliminate corrosion due to the high concentration of chlorides. Alternative solutions to the problem are improving the quality of the feedwater, which will enable the production of saturated steam with better parameters, or consider the change of the steel grade.

\section{References}

[1] G. R. Mirshekari, E. Tavakoli, M. Atapour, B. Sadeghian, Microstructure and corrosion behavior of multipass gas tungsten arc welded $304 \mathrm{~L}$ stainless steel, Materials and Design (2014), 55, 905-911.

[2] A. Świerczyńska, G. Rogalski, D. Fydrych, Badania struktury i właściwości spawanych austenitycznych rur wymienników ciepła, Welding Technology Review (2010), vol. 82 (6), 11-16.

[3] K. R. M. Rao, S. Mukherjee, P. M. Raole, I. Manna, Characterization of surface microstructure and properties of low-energy high-dose plasma immersion ion-implanted 304L austenitic stainless steel, Surface and Coating Technology (2005), 200, 2049-2057.

[4] S. Ghosh, V. P. S. Rana, V. Kain, V. Mittal, S.K. Baveja, Role of residual stresses induced by industrial fabrication on stress corrosion cracking susceptibility of austenitic stainless steel Materials \& Design (2011), vol. 32 (7), 3823-3831

[5] E. Tasak, A. Ziewiec, Spawalność materiałów konstrukcyjnych, Wydawnictwo JAK, Kraków (2009).

[6] H. Ezuber, A. Alshater, S. O. Nisar, A. Gonsalvez, S. Aslam, Effect of Surface Finish on the Pitting Corrosion Behavior of Sensitized AISI 304 Austenitic Stainless Steel Alloys in $3.5 \% \mathrm{NaCl}$ Solutions, Surface Engineering and Applied Electrochemistry (2018), 54, 73-80

[7] R. E. Melchers, I. A. Chaves, R. Jeffrey, A Conceptual Model for the Interaction between Carbon Content and Manganese Sulphide Inclusions in the Short-Term Seawater Corrosion of Low Carbon Steel, Metals (2016), vol.6(6), 132.
[8] T. Prosek, A. Iversen, C. Taxén, D. Thierry, Low-Temperature Stress Corrosion Cracking of Stainless Steels in the Atmosphere in the Presence of Chloride Deposits, CORROSION (2009), vol. 65 (2), 105-117.

[9] S. Ghos, , V. P. S. Rana, V. Kain, V. Mittal, S.K. Baveja, Role of residual stresses induced by industrial fabrication on stress corrosion cracking susceptibility of austenitic stainless steel, Materials and Design (2011), 32, 3823-3831.

[10] P. Roffey, E. H. Davies, The generation of corrosion under insulation and stress corrosion cracking due to sulphide stress cracking in an austenitic stainless steel hydrocarbon gas pipeline, Engineering Failure Analysis (2014), 44, 148-157.

[11] PN-H-86020:1971 Stal odporna na korozję (nierdzewna i kwasoodporna) - Gatunki.

[12] PN-EN 10028-7:2016-09 wyroby płaskie ze stali na urządzenia ciśnieniowe - Część 7: Stale odporne na korozję

[13] I.I. Vasilenko, R.K. Melehov, Korrozionnoe rastreskivanie stali, Kiev (1977) (Василенко И.И., Мелехов Р.К.: Коррозионное растрескивание сталей, Киев 1977).

[14] G. Rogalski, J. Łabanowski, D. Fydrych, A. Świerczyńska, Wpływ obróbki cieplnej na właściwości spawanych austenitycznych rur wymienników ciepła, Welding Technology Review (2014), vol. 86 (6), 24-31. 